\title{
THE EMERGENCE OF ISLAMIC BANKING: Development, Trends, and Challenges
}

\author{
Waeibrorheem Waemustafa \\ Faculty of Finance and Banking, Universiti Utara Malaysia
}

\begin{abstract}
Islamic banks have emerged over the last four decades and witnessed remarkable growth in terms of numbers of new Islamic banks being established all over the world. This expansion is paralleled to an equal high growth in Islamic banking education. There exist various colleges and universities offering courses related to Islamic banking and finance. This paper maps the growth and development of Islamic banking industry from 1963 to the $21^{\text {st }}$ century both in terms of education, trend and challenges. This study could provide a systematic documentation of the rapid growth in the Islamic banking industry and able to attract new participants. However, the rapid development in the global financial markets poses various challenges to Islamic banking in the present era. These issues and challenges need to be addressed very carefully in order to sustain the rapid growth it experienced before. This paper highlights the various developments, issues and challenges confrontingthe Islamic banking to offer recommendations for further improvement.
\end{abstract}

Keyword: Islamic banking, development, trends and challenges.

\section{Introduction: A Perspective On Islamic Banking}

An Islamic banking evolution signal a great changes to the financial industry, as evidence from growing numbers of new participant in Islamic bank today. The ultimate justification of why new participant interested to joining in this industry is mainly due to its unique financing structures that quite provide more flexible settlement procedure compare to strict penalty imposed by conventional bank. Islamic financial institution is established to operate commercial banking activities that free from any prohibited element in Islamic shariah jurisprudence such as riba, maisir, jahala, and gharar. The replacement of interest to profit and loss sharing is aim at promoting just and equity when contribute in term of risk and return. The emergence of Islamic banks has create new frontier in financial intermediation industry, where the nature of Islamic banks that provides more alternative banking service that based on equity based, debt based and fee based. Islamic banking develops its alternative mode of financing inline with the needs of today financing needs of its clients. The new participants in Islamic banks should be aware that to become fully participate in interest free banking scheme the bankers need to be educated in the area of Shariah especially in its Fiqh related to financial matter before embarked into Islamic banking industry.

Very often Islamic banks being criticized especially from conventional secular in term of similarities of Islamic banks to traditional interest based banking, this issue is arise when the practice of Islamic banking activities is not carefully exercised the Shariah principle that regulated each mode of financing before its concluded. Though the growth of Islamic banking till today has proven that Islamic bank is feasible and able to operate side by side to traditional banking with wide variety of products that able to cater to the household and corporate clients.

\section{SOURCES OF ISLAMIC BANKING UNDERSTANDING}

The feasibility of Islamic banking may not be materialized without the ongoing contribution of scholars today and in the past. The continue process of research in Islamic banking and documentation enable Islamic bankers to move to another stage of development. There are various Islamic financial institution and body such as ISLAMIC FINANCIAL SERVICE BOARD (IFSB), ISLAMIC RESEARCH AND TRAINING INSTITUTE (IRTI) and CENTRAL BANK OF MALAYSIA, these body has contribute in term of supervisory role, research and publication in the area of Islamic banking and finance. Bank Islamic Malaysia on other hand demonstrate its capabilities to become one of a very innovative Islamic bank that enable to provide varieties of product based of Islamic Muamalat principle.

- Academic Journals; These are refereed academic journal that contain article dealing with research, methodology, result and application of research. Such as International journal of Islamic financial services, Middle East Policy, International Journal of social economics, Arab Law Quarterly, International Journal of Islamic Financial Services, Islamic Economics Studies, Islamic Horizons, Journal of King Abdulaziz University (Islamic Economics), Journal of Islamic Banking and Finance, Journal of Research in Islamic Economics and Review of Islamic Economics. 
- Textbooks on Islamic banking. The focus area of these books stressed on the development, operation, performance and risk management. For example (obaidullah 2005) "Islamic financial services", (Siddiqui 1979) "banking without interest" (Usmani 2002) "An introduction to Islamic finance". These scholars among the pioneers to advocate the feasibility of putting theory of Islamic banking into practice once again post closure of first Islamic banks that was operate in Egypt in 1963. The fundamental sources of Islamic banking is basically derived from Holy Quran and Sunnah through these legal maxims found in discipline of fiqh muamalat in which detail rule and condition applied in any matter pertain to economic relations among human being is carefully discussed in fiqh jurisprudence.

\section{The Emergenece Of Islamic Banking Education}

The transformation process of Islamic banks started since 1963 in Egypt; however major development started since 1970 where large number of commercial bank serving retail customer based on Islamic principle; however in 1980 Islamic banks has shift toward investment bank through profit and loss sharing. In 1990 Islamic financial institution become increasingly more innovative and developing more complex instrument to meet the demand of its clients today.

The study of Islamic banking in 1980 was more focused on the fundamental principle of Islamic banking which is based on profit and loss sharing (Ariff 1988) and (Wilson 1997) the Islamic banking characteristic and development study in late 1980 considered to be at feasibility stage. However, in 1990 the focused area of studies has move one step further in the application and practices of Islamic banking in different economic setting (Khan and Mirakhor 1990) and (Khaf et al 1998) the study elaborate process and concept of interest elimination and replaced by profit and loss sharing in Pakistan and Iran, (Hasan 1999) explore theory and practice of equity based financing in Bangladesh. In the study of (Metawally 1997) and (Samad and Hasan 1999) the study attempt to compare performance of Islamic banking to conventional banks, during 1990 many research in other discipline such as marketing (Haron and Ahmad 1994) and (Gerrard and Cunningham 1997) where patronage factor of Islamic banks was studies in the dual banking system. (Rosly and Bakar 2003) elaborate and compare the efficiency usage of assets between Islamic and conventional banks, (Kaleem and Isa 2003) study demonstrate how Islamic bank can substitute to the conventional banks.

Today Islamic banking operate on parallel basis with conventional banks where competition is stiffed (Naser and Moutinho 1997) demonstrate how Islamic banks can take advantage of strategic marketing knowledge in becoming competitive to conventional banks. (Metawa and Almossawi 1998) investigate banking behavior of Islamic banking customers. (Sundararajan and Errico 2002) and (Obaidullah 2000) In the $21^{\text {st }}$ century the focus of the studies in Islamic banking and shift to the area of risk management (Abdul Karim et al 2005) especially various type of risk and its exposure to Islamic banking, (Ali 2004) study various mode of finances to determined liquidity risk, (Muljawan et al 2004) suggest how the implication of capital adequacy and regulation on non-profit and loss sharing assets of Islamic banks, (Errico and Farahbaksh 1998) stress on supervisory in Islamic banking structure.

\section{A Historical Context Of Islamic Banking Education}

Islamic banking revived again in the Egyptian town of Mit Ghamr in 1963 where such experiment was last until 1967, today Islamic banks growth at an amazing rate that draw attention to the interest based bank to participate in the interest free banking institution. The success of Islamic banks today is depend on ability to overcome constraint of resources such as know how human capital. Today Islamic bankers are normally brought from conventional banks to handle day to day operation of Islamic banks; the issue of competencies is always adress by academicians and Islamic banks clients.

However Islamic banks further develop during late 1970s where the establishment of Islamic development bank (IDB) in 1975 that actively involved research related to Islamic banking development, Islamic research and training institute (IRTI) was established to facilitate research and training carried out by Islamic development bank scholars. Today various universities around the world offering course in the area of Islamic bank studies. In Malaysia for instance has established international Islamic banking and finance education INCEIF established in 2006 offers certificate in Islamic banking and finance, the centre focus on developing Islamic bankers that equipped with necessary shariah and banking knowledge that essential to potential and existing Islamic bankers. 


\section{Table 1: ISLAMIC BANKING EDUCATION INSTITUTIONS}

\begin{tabular}{lcc}
\hline \multicolumn{1}{c}{ INSTITUTE NAME } & YEAR & COUNTRY \\
\hline Islamic Research Centre, King Abdulaziz University & 1977 & Saudi Arabia \\
Islamic Research And Training Institute (IRTI) & 1981 & Saudi Arabia \\
Bahrain Institute of Banking and Finance (BIBF) & 1981 & Bahrain \\
Emirate Institute for Banking and Financial Studies (EIBFS) & 1983 & UAE \\
Institute of Islamic Banking and Insurance (IIBI) & 1991 & UK \\
Muamalat Institute, Bank Muamalat (MIBM) & 1992 & Indonesia \\
Centre for Islamic Economics (CIE) & 1992 & Pakistan \\
Harvard Islamic Finance Project (HIFP) & 1995 & US \\
Bank Islam Research and Training (BIRT) & 1995 & Malaysia \\
Islamic Banking and Finance Institute Malaysia (IBFIM) & 2001 & Malaysia \\
International Centre for Education in Islamic Finance (INCEIF) & 2006 & Malaysia \\
\hline
\end{tabular}

Islamic banking education institution has been established around the world for the last three decades. One of the earliest was Saudi Arabia has been promoting Islamic banking through the establishment of Islamic research and training institute (IRTI) that extensively engaged in research and training in the area of Islamic banking. The growing interest in the area of Islamic banking education has spread even further to south east asia country such as Malaysia where Islamic banking is encouraged with its continues innovation in the product development base on shariah principle. With recent establishment of international centre for education in Islamic finance (INCEIF) by central bank Malaysia further stimulate development of potential Islamic bankers to cater future shortage of Islamic banking human capital.

\section{The Current States Of Islamic Banking Education}

The progress of Islamic banking theory and practice has evolved for more than three decades, the initial progress was in 1970s where the scholar in Islamic banking discipline strive to demonstrate the feasibility of putting Islamic banking theory into practice, major debate was on the basis of equity based financing and its potential contribute toward economic development, employment, and just distribute of income among entrepreneur and venture capital. Though agency problem and information asymmetry become major obstacle to promote profit and loss sharing based in the Islamic banking operation.

In 1990s witnessed a very great interest from new participant in interest free banking especially in Malaysia where conventional banks being license to provide interest free financial service and products. Thus Islamic banks needs to become more competitive when operating side by side to dual banking, the focus were in-term of product superiority, financial performance and ethic issues.

In $21^{\text {st }}$ century Islamic banks realized that the risk exposed is considerably higher compared to conventional bank, where the nature Islamic mode of financing does provide higher return and of course with higher risk especially when the Islamic banking instrument is not carefully exercise according to shariah principle. The risk management area currently becomes a very attractive research area to Islamic banking scholars to come up with prudent risk management theory and practice. Islamic banks today have far more complex than previously was, where more innovative and complex instrument is offered by Islamic banks. Risk management is one of most attracted area for today scholars as more growth in the financial engineering. Islamic financial institution today does agreed with the profit and loss sharing principle; however in practice Islamic bank may favored debt based financing instead of equity based financing. This is because the risk preference may not generalize to all banks.

\section{Future Challenges For Islamic Banking Education}

There are challenges facing Islamic banks today that are categories into short-term and long-term challenge. Islamic banks today become more concerned in the short-term survivability, where this focus has create obstacle to implement profit and loss sharing. Today debt based mode of financing is considered as main sources of income to Islamic banks, such as Murabahah financing which is dominate over other mode of finance with its low risk nature. However debt base instrument is only favorable during good economic condition which will have severe effect during bad economy compare to equity base finance.

Today Islamic bank is quite conservative when involved with equity based financing, where longerterm investment which is based on equity financing is maintained at lowest level compared to debt based financing. The continues dependent of debt based financing may led to less effort to Islamic banks participant to find solution to promote profit and loss sharing principle. This long-term negative effect may led to reputation risk and bad image to Islamic banker or worst situation where the unique identity of advocating profit and loss sharing of Islamic banking may no longer exist in near future. According to (Tahir 2003) the need for Islamic 
banking today to have standardization for the name used when refer to the products and services offered by Islamic banks, pricing formula, public awareness and training of banking professional in the use of Islamic financial products are of the major issues that facing Islamic to date. Though prudent regulation and control of Islamic banking is one of foremost important government intervention to ensure the success of Islamic banking especially at the enforcement stage to resolve any dispute that may arise to safeguard to ensure every party right is protected.

\section{LACK OF UNIFORMITY OF SHARIAH INTEPRETATION}

Islamic banking relies heavily on the reputation and image toward promoting just and equity financing on the basis of profit and loss sharing. Through this ability Islamic banks will be able to become truly operate based on shariah principle of profit and loss sharing. Inability to conform to the fundamental principle that may cease the trust of its client toward the banks and this may led to serious inability to sustain long-term. (El-Gamal 2000) The inconclusive definition of permissible riba and gharar is further creates endless debate among Islamic banking scholars.

This further led to the formation of shariah compliance risk which is a severe effect of the effort to advocate equity based financing that based on profit and loss sharing. Effective collaboration effort among Islamic banking scholars all over the world should be established in order to come up with credible and reliable conclusion on any issues that need their collective attention to prevent causing negative image toward promoting sustainable Islamic banking operation.

\section{Shortage Of Islamic Banking Educations}

The ultimate challenges of Islamic banking today is in the area of ineffective education (Abdul hamid et al 2001) where educating clients through marketing effort is not taken as serious matter to Islamic bankers ever since. As witnessed today Islamic banking client is not limited to Muslim ummah only, though non-Muslim clients also become an important contributor to the growth of the Islamic banks industry. However, marketing effort of Islamic banks today is considered at very minimum stages when compared to conventional banks interest based.

Though the most critical challenging issues to Islamic banks today is in term of the effective process of educating non-Islamic shariah background bankers to participate in Islamic banking industry. This holistic Islamic banking system should be first overcomes in order to achieved sustainable Islamic banking system. Where, scholars of shariah in the area of fiqh should become part of the joint collaboration of Islamic banks in order to derive toward collective conclusion especially in the issues of shariah compliance. Islamic banking education should take one step beyond in term of educating Islamic bankers to become more competence when dealing with its service and product. Today Islamic banking personnel are important agents that act as mediator to educate its clients toward more understanding on the unique product of Islamic banking products. Especially, when managements of Islamic banks which is not from Islamic banking or shariah background. This further create negative perception of existing and potential client on whether Islamic banks really Islamic in term of competencies to carry out Islamic banking activities toward shariah ultimate objective that promote just and equity.

\section{Conclusion; A Call To Action}

The Islamic banking education today should work together with Islamic body such as Al-Azhar University in Egypt, and other prominent figh discipline in Islamic world to ensure uniformity in the interpretation of divine sources such as Holly Quran and Sunnah. This will ensure long-term uniformity of academician and Islamic scholars, as witnessed today very often the interpretation of riba is considered to be not standardized because of very poor communication between Islamic banking researchers that has no Islamic banking background. Thus the curriculum of future Islamic banking education should involved shariah scholar in universities around the world in order to come up with much more acceptable standard to all Islamic scholars around the world.

The focused of Islamic bankers today should be on parallel basis, where the Islamic bankers and its clients should be provided adequate education in the area of Islamic banking concept and application. Where serious efforts to discover feasible approach that bring back profit and loss sharing principle to Islamic banks to be major sustainable mode of financing. The advantage is rewarded through profit and loss sharing mechanism which is greater when tradeoff with the risk exposed. Islamic banks may be viewed as similar to interest based especially when the proportion of murabahah is dominate other instruments, where Islamic banks asset portfolio is largely on debt based financing. Thus education of today and future should strive to come up with feasible way to resume profit and loss sharing mode to Islamic banks. This can be achieved with collaboration of all available party concerned in Islamic banks regardless of top level management, regulator, shariah supervisory and other Islamic banking institution and education body. the joint effort is the only solution to 
make holistic Islamic banking operation to be truly unique in term of promoting business creation, employment and economic development on the basis of just distribution of income through profit and loss sharing mechanism.

In present Islamic banks face with constraints on its financing mechanism where highly dependent on murabahah debt based financing as a main sources of income to Islamic banks. This is further exposed it self to the risk during bad economic condition where debt based financing cease to sustain especially during economic crisis. Thus the on going effort to develop Islamic banking system that able to sustain and growth with the used of equity based financing musharakah and mudarabah should become a collective measure to all Islamic banks stakeholders. Through the development of effective Islamic banking system that able to develop competence bankers to ensure sustainability without compromising Islamic value is the collective challenges to all participants in Islamic banks.

However the effort of promoting and sustain Islamic banking operation is an on going effort where all participants including practitioner, Islamic banking scholars, regulator and other stakeholders in Islamic banks do have direct and indirect roles toward continues development of Islamic banking concepts and practices. All these measure should not compromise Islamic value in order to established Islamic financial institution that conform to shariah principle in which derived from the Holly Quran and Sunnah that its existence is aimed to benefit all mankind toward just and equity when deal with matter related to financing activities.

\section{References}

[1] Abdul Halim Abdul Hamid, N. M. N. (2001). "A Study On Islamic Banking Education and Strategy for the Millenium-Malaysian Experience." International Journal of Islamic Financial Services 2(4)

[2] $\quad$ Abdus Samad, K. H. (1999). "The Performance of Malaysian Islamic bank during 1984-1997:an exploratory study." International Journal of Islamic Financial Services 1(3).

[3] Ahmad Kaleem, M. I. (2003). "Causal Relationship between Islamic and conventional banking instrument in Malaysia." International Journal of Islamic Financial Services 4(4).

[4] Ali, S. S. (2004). Islamic Mode of Finance and Liquidity Risks. Conference on Monetory Sector in Iran: Structure, performance and challenging issues, Tehran, Iran.

[5] Ariff, M. (1988). "Islamic Banking." Asia-Pacific economics literature 2(2): pp 48-64.

[6] Dadang Muljawan, H. A. D., Maximilian J.B. Hall (2004). "A Capital adequacy framework for Islamic Banks the need to reconcile depositors risk aversion with managers risk taking." Applied Financial Economics 14: pp 429-441.

[7] El-Gamal, M. A. (2000). An Economic Explication of the Prohibition of Gharar in Classical Islamic Jurisprudence. $4^{\text {th }}$ International Conference on Islamic Economics, Leicester, UK.

[8] Hasan, M. K. (1999). "Islamic banking theory and practices: the experience of Bangladesh." Managerial Finance 25(5).

[9] Kamal Naser, L. M. (1997). "Strategic marketing management: the case of Islamic banks." International journal of bank marketing 15(6): pp 187-203.

[10] Luca Errico, M. F. (1998). "Islamic Banking: Issues in prudential regulation and supervision." IMF Working Paper

[11] Obaidullah, M. (2005). Islamic Financial Services. Jeddah, Scientific Publishing, King Abdulaziz University.

[12] Melina Abdul Karim, J. C. Y. H., Peter Verhoeven (2005). "Islamic Financing and Bank Risks: the case of Malaysia." Thunderbird International Business Review 47(1): pp 75-94.

[13] Metwally, M. M. (1997). "Differences between the financial characteristics of interest free banks and conventional banks." European Business Review 97(2): pp 92-98.

[14] Mohsin S. Khan, A. M. (1990). "Islamic Banking: experience in the Islamic republic of Iran and Pakistan." Economic Development and Cultural Change 38(2): pp 353-75.

[15] Monzef Khaf, A. A., Hani Homoud (1998). "Islamic Banking and Development." Islamic Research and Training Institute.

[16] Obaidullah, M. (2000). "Islamic Risk Management: Toward a greater ethics and efficiency." International Journal of Islamic Financial Services 3(4).

[17] Philip Gerrard, J. B. C. (1997). "Islamic Banking in Singapore." International Journal of Bank Marketing 15(6).

[18] Wilson, R. (1997). "Islamic Finance and Ethical Investment." International Journal of Social Economics 24(11).

[19] Saad A Metawa, M. A. (1998). "Banking behavior of Islamic banking customer: perspectives and implication." International Journal of Bank Marketing 16(7).

[20] Saiful Azhar Rosly, M. A. A. B. (2003). "Performance of Islamic and mainstream banks in Malaysia." International Journal of Social Economics 30(12): pp 1249-1265.

[21] Siddiqui, N. (1979). Banking Without Interest. Delhi-6, Markazi Maktaba Islami: pp 224.

[22] Sudin Haron, N. A. (1994). "Bank patronage factors of Muslim and non-Muslim customers." International Journal of bank marketing 12(1).

[23] Tahir, S. (2003). Current Issues in the Practice of Islamic Banking. Course on Islamic Bangking and Finance, TEHRAN, Iran, Central Bank of Iran \& IRTI.

[24] Usmani, M. T. (2002). An Introduction to Islamic Finance. Arab and Islamic Laws Series, Kluwer Law International: pp 26.

[25] V. Sundararajan, L. E. (2002). Islamic Financial Institutions and products in the global financial system: key issues in risk and management challenges ahead. IMF Working paper, Conference on 'Risk management in Islamic financial system' organized by the Iran Banking institute. 